\title{
16. Some Material Properties of Cerium Sesquioxide
}

\author{
By \\ Toshiyuki SATA and Masahiro YOSHIMURA \\ (Research Laboratory of Engineering Materials, \\ Tokyo Institute of Technology, Ōokayama, Meguro-ku, Tokyo)
}

\section{Introduction}

Since rare earth elements are generally stable in a trivalent state in normal conditions, their oxides exist as forms of sesquioxide $\left(\mathrm{Ln}_{2} \mathrm{O}_{3}\right)$ in air. However, cerium usually exists in a quadrivalent state in air, namely in the form of $\mathrm{CeO}_{2}$ as oxide. In this reason, the studies of the material properties of cerium oxides have been mainly carried out for $\mathrm{CeO}_{2}$ instead of $\mathrm{Ce}_{2} \mathrm{O}_{3}$. Few properties of cerium sesquioxide have been discussed, i.e. the electrical conductivity, the chemical stability, and the melting point were reported by $\mathrm{E}$. Friedrich et $\mathrm{al}^{1)}$. in 1927, and the resistivity ${ }^{2}$ and the thermal expan$\operatorname{sion}^{3)}$ were studied by M. Föex in 1944 and 1946, respectively. In these studies, however, the considerations for the experimental devices and conditions seem to be insufficient, and it is probable that $\mathrm{Ce}_{2} \mathrm{O}_{3}$ have changed into the intermediate phase.

$\mathrm{Ce}_{2} \mathrm{O}_{3}$ is prepared from $\mathrm{CeO}_{2}$ by reduction with $\mathrm{H}_{2}, \mathrm{CO}$, etc. and is golden or mustard yellow in color. Its crystal system is hexagonal $\mathrm{La}_{2} \mathrm{O}_{3}$-type: $a=3.889 \AA, c=6.054 \AA^{4}$. It is well known that $\mathrm{La}_{2} \mathrm{O}_{3}$ structure is related with $\mathrm{CaF}_{2}$ structure of $\mathrm{CeO}_{2}$ and that several intermediate phases ${ }^{4), 5}$ which are represented by $\mathrm{CeO}_{2-x}$ exist in the composition range between $\mathrm{Ce}_{2} \mathrm{O}_{3}$ and $\mathrm{CeO}_{2}$.

In this work, the stability, the melting point, the thermal expansion coefficient, the electrical conductivity and the magnetic susceptibility have been studied for powdered sample and sintered bodies of $\mathrm{Ce}_{2} \mathrm{O}_{3}$, as a part of the investigations of the sub-oxides or lower oxides for engineering materials.

\section{Experimental}

\subsection{Preparation of $\mathrm{Ce}_{2} \mathrm{O}_{3}$ specimen}

The starting material was high purity $\mathrm{CeO}_{2}$ powder (99.95\%) obtained from Lindsay Chemical Corp., Chicago. The observed magnetic suscepti- bility $\left(0.14 \times 10^{-6} \mathrm{emu} / \mathrm{g}\right)$ of this $\mathrm{CeO}_{2}$ was in agreement with the literature value ${ }^{b)}$ of carefully purified $\mathrm{CeO}_{2}$ especially not to contain $3 d$ elements. The spectroscopic analysis was also undertaken. The lattice constant of this $\mathrm{CeO}_{2}$ was $a=5.410 \AA$, which agrees with the literature value ${ }^{4}$.

$\mathrm{CeO}_{2}$ powder was pressed with some methanol at $1 \mathrm{t} / \mathrm{cm}^{2}$ into a round pellet $(10 \mathrm{~mm} \phi \times 3 \mathrm{~mm})$. The pellet was hanged using a molybdenum wire in a high alumina tube of a $\mathrm{SiC}$ electric furnace and heated in an atmosphere of flowing dry hydrogen $(0.2 \mathrm{l} / \mathrm{min})$. By keeping for $2 \sim 10$ hours at $1400^{\circ} \mathrm{C}$, the reduction into $\mathrm{Ce}_{2} \mathrm{O}_{3}$ was accomplished.

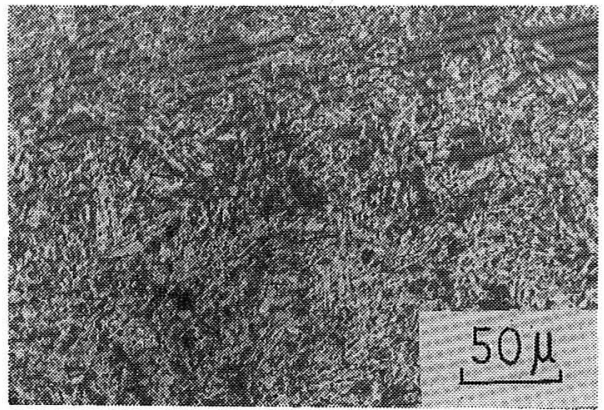

(a)

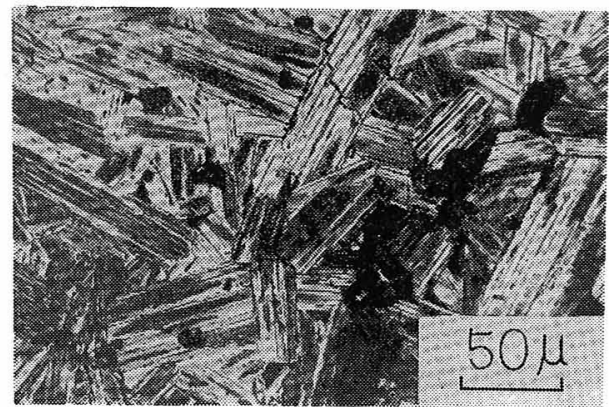

(b)

(a) Sintered for 4 hours at $1400^{\circ} \mathrm{C}$.

(b) Sintered for 2 hours at $1700^{\circ} \mathrm{C}$.

Fig. 1. Microphotographs of the surface of the $\mathrm{Ce}_{2} \mathrm{O}_{3}$ specimen. 
After the treatments, the samples were dropped into an iced acceptor for quenching. When they were slowly cooled, $\mathrm{Ce}_{2} \mathrm{O}_{3}$ changed into the intermediate phase by some oxidation. The lattice constants of $\mathrm{Ce}_{2} \mathrm{O}_{3}$ obtained in this treatment were determined to be $a=3.892 \AA, c=6.064 \AA$. The reduction process from $\mathrm{CeO}_{2}$ to $\mathrm{Ce}_{2} \mathrm{O}_{3}$ and the behaviors of the intermediate phases are described in another report $^{7}$.

For the measurements of the thermal expansion and the electric conductivity, $\mathrm{CeO}_{2}$ powder was hydrostatically pressed into a bar form at $3 \mathrm{t} / \mathrm{cm}^{2}$ and was sintered in an atmosphere of hydrogen as described above in order to obtain $\mathrm{Ce}_{2} \mathrm{O}_{3}$ bar specimen $\left(4 \times 4 \times 25 \mathrm{~mm}^{3}\right)$. The sintered density was found to be $88 \%$ of theoretical.

A microphotograph of the polished surface of the sintered specimen is shown in Figure 1(a). A microphotograph of the specimen sintered for 2 hours at $1700^{\circ} \mathrm{C}$ is also shown in Figure 1(b) for references, though the reduction did not proceed furthermore $(<1.50$ of $\mathrm{O} / \mathrm{Ce}$ atomic ratio) at temperatures above $1400^{\circ} \mathrm{C}$

\subsection{Stability}

$\mathrm{Ce}_{2} \mathrm{O}_{3}$ powder and sintered pellets were heated in air in a platinum crucible in order to observe their oxidation behaviors. Weight increasings were also determined by means of thermogravimetric analysis (TGA). The reactivities of $\mathrm{Ce}_{2} \mathrm{O}_{3}$ with water, acids and alkaline solutions were studied.

\subsection{Melting point}

A small piece of $\mathrm{Ce}_{2} \mathrm{O}_{3}$ which was hanged by a tungsten wire in a tungsten tube heater was heated in an atmosphere of flowing dry hydrogen. The melting behavior of the test piece was observed through a window on the shell of the furnace. Temperatures were measured with a $\mathrm{W} \cdot 5 \% \mathrm{Re}-\mathrm{W}$. $26 \%$ Re thermocouple situated near by the test piece. The thermocouple was calibrated with the melting points of $\mathrm{Au}, \mathrm{Pd}, \mathrm{Pt}, \mathrm{Rh}$ and Ir metals using the same method as above. The details of this method and the tungsten furnace used here were previously reported by one of the authors ${ }^{8}$.

\subsection{Thermal expansion}

A horizontal dilatometer with a dialgauge $(0.001$ $\mathrm{mm}$ ) was used for measurements where the sample holder and the extension rod were made from high purity alumina of Degussa Co., Germany. The experiments were carried out in temperatures between a room temperature and $1400^{\circ} \mathrm{C}$ with heating and cooling rates of about $4^{\circ} \mathrm{C} / \mathrm{min}$. in an atmosphere of flowing hydrogen $(0.2 l / \mathrm{min})$. The thermal expansion coefficients were calculated from the thermal expansion curve obtained. For comparison, measurements for $\mathrm{CeO}_{2}$ specimen sintered for 2 hours at $1500^{\circ} \mathrm{C}$ in air were carried out in air.

\subsection{EIectrical conductivity}

Both ends of a bar specimen were coated with platinum paste for platinum electrodes contact and two platinum wires were wrapped tightly around the bar as potential probes. The a.c. bridge of $1000 \mathrm{cps}$ (Yokogawa Electric Work Co., Tokyo, Type BV-Z-13A) was mainly used for measurements. Four probes or two probes d.c. methods were also attempted. The differences of measurements between a.c. and d.c. method were negligible small. A complete description of the $\mathrm{SiC}$ furnace and electrodes assembly is shown in Figure 2. The atmosphere was chiefly dry hydrogen, though argon, vacuum and air were also employed in a lower, temperature range. The composition of the samples was found to be $\mathrm{Ce}_{2} \mathrm{O}_{3.042}$ by means of the perfect oxidation method to $\mathrm{CeO}_{2}$.

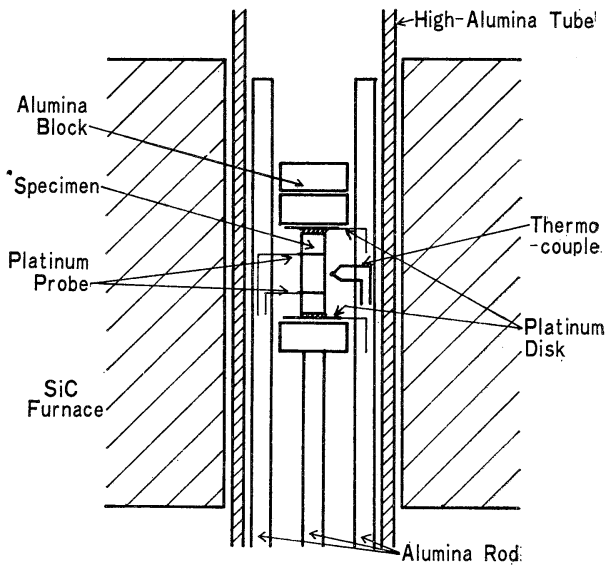

Fig. 2. Arrangements and electrodes assembly for the electrical conductivity measurement.

\subsection{Magnetic susceptibility}

A torsion type magnetobalance (Shimadzu Seisakusho Ltd., Kyoto, Type MB-II) was used for measurements. The block diagram is shown in Figure 3. A guaranteed reagent of copper sulfate, $\mathrm{CuSO}_{4} \cdot 5 \mathrm{H}_{2} \mathrm{O}$, which was purified with a procedure of two times recrystalization, wes employed as the standard material.

The magnetic susceptibility of $\mathrm{CuSO}_{4} \cdot 5 \mathrm{H}_{2} \mathrm{O}$ is known to be $5.84 \times 10^{-6} \mathrm{emu} / \mathrm{g}$ at $293^{\circ} \mathrm{K}$. The experimental conditions were as follows :

Temperature range $\quad 77^{\circ} \sim 300^{\circ} \mathrm{K}$

Field strength $\quad 10,500$ Oersted

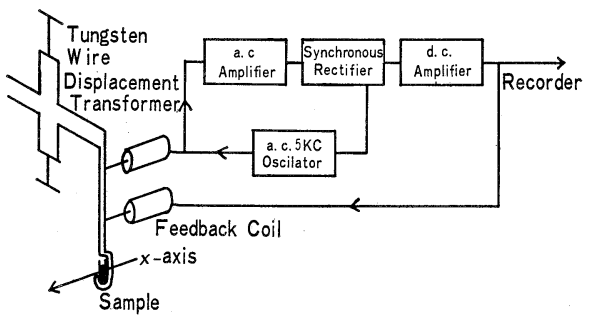

Fig. 3. Block diagram of the magnetobalance. 
Heating rate

$1.5^{\circ} \mathrm{C} / \mathrm{min}$

Atmosphere

dry $\mathrm{H}_{2}$ at $200 \mathrm{mmHg}$

The composition of sample was found to be $\mathrm{Ce}_{2} \mathrm{O}_{3.047}$.

\section{Results and Discussions}

\subsection{Stability}

$\mathrm{Ce}_{2} \mathrm{O}_{3}$ was very unstable in air and the oxidation of $\mathrm{Ce}_{2} \mathrm{O}_{3}$ occured even at a room temperature. When a pellet was warmed in air, its surfaces changed from mustard to white in color and swelled up above ca. $100^{\circ} \mathrm{C}$. The oxidation reaction was remarkably exothermic, so it was often observed that $\mathrm{Ce}_{2} \mathrm{O}_{3}$ ignited spontaneously on exposure to the atmosphere. The weight increasing curves of $\mathrm{Ce}_{2} \mathrm{O}_{3}$ powder and pellet with the oxidation to $\mathrm{CeO}_{2}$ were shown in Figure 4, where the formations of the intermediate phases in this oxidation process were not observed.

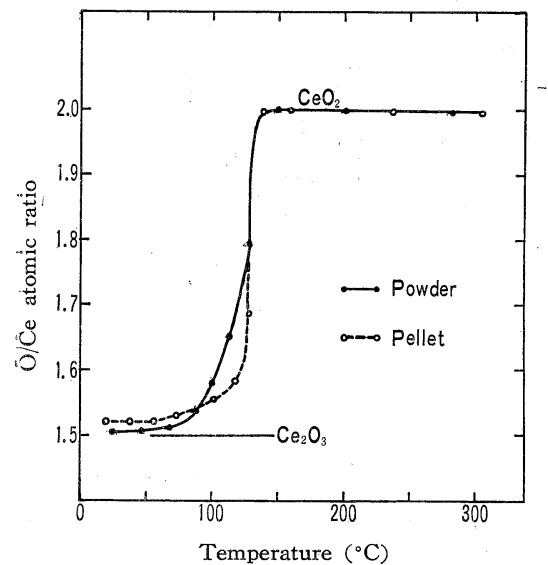

Fig. 4. Weight increasing curves of $\mathrm{Ce}_{2} \mathrm{O}_{3}$ with the oxidation into $\mathrm{CeO}_{2}$ in air.

When a following heterogeneous reaction is considered,

$$
\mathrm{Ce}_{2} \mathrm{O}_{3}+1 / 2 \mathrm{O}_{2}=2 \mathrm{CeO}_{2}
$$

Free energy change of this reaction is given by

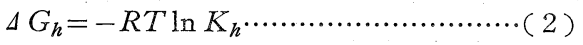

where $K_{h}$ is the equilibrium constant and equal to square root of oxygen partial pressure $\left(P_{\mathrm{O}_{2}}{ }^{1 / 2}\right)$.

From the first law of the thermodynamics, the following equation is known :

$$
\Delta G_{h}=\Delta H_{h}-T \Delta S_{h}
$$

By F.A. Kuznetzov and his coworker ${ }^{9}, \mathrm{H}_{298.2^{\circ} \mathrm{K}}$ of $\mathrm{CeO}_{2}$ and $\mathrm{Ce}_{2} \mathrm{O}_{3}$ were given to be $-260.18 \mathrm{kcal} /$ mole and $-434.93 \mathrm{kcal} / \mathrm{mole}$, respectively, and $\bar{C}_{p}$ of $\mathrm{CeO}_{2}$ and $\mathrm{Ce}_{2} \mathrm{O}_{3}$ to be $15.03+2.513 \mathrm{~T} \times 10^{-3} \mathrm{cal} /$ mole ${ }^{\circ} \mathrm{K}$ and $25.17+6.327 T \times 10^{-3} \mathrm{cal} / \mathrm{mole}^{\circ} \mathrm{K}$, respectively. Using these values, the equilibrium oxygen pressures $\left(\mathrm{P}_{\mathrm{O}_{2}}{ }^{1 / 2}\right)$ of $\mathrm{Ce}_{2} \mathrm{O}_{3}$ were calculated to be $1.3 \times 10^{-58} \mathrm{~atm}$ at $298^{\circ} \mathrm{K}$ and $9.0 \times 10^{-13} \mathrm{~atm}$ at $1000^{\circ} \mathrm{K}$, respectively. By comparison, the observed values of $P_{\mathrm{O}_{2}}{ }^{1 / 2}$ was obtained to be $5.1 \times 10^{-15}$ atm at $1000^{\circ} \mathrm{K}$ by D.J.M. Bevan ${ }^{5}$. On the basis of above discussions, it is obviously understood that the oxidation of $\mathrm{Ce}_{2} \mathrm{O}_{3}$ can not be prevented in an ordinary atmosphere as argon, vacuum to say nothing of air.

$\mathrm{Ce}_{2} \mathrm{O}_{3}$ did not dissolve in alkaline solutions but very slowly in acids and reacted with water in the same manner as $\mathrm{La}_{2} \mathrm{O}_{3}$ and produced white material which gradually changed into $\mathrm{CeO}_{2}$ in several days or dehydration process. Details of this hydrated material was not studied in this work.

\subsection{Melting point}

The obtained values of the melting point of $\mathrm{Ce}_{2} \mathrm{O}_{3}$ are shown in Table 1 . Although a piece of $\mathrm{CeO}_{2}$ pellet was used in No. 3 experiment, it would be reduced into $\mathrm{Ce}_{2} \mathrm{O}_{3}$ in hydrogen. The quenched samples after melting were easily separated from a tungsten wire by crashing and was confirmed to be $\mathrm{Ce}_{2} \mathrm{O}_{3}$ by $\mathrm{X}$-ray diffraction analysis.

Table 1. Melting point of $\mathrm{Ce}_{2} \mathrm{O}_{3}$.

$\begin{array}{cccc}\text { No. } & \text { e.m.f. }(\mathrm{mV}) & \text { Melting point }\left({ }^{\circ} \mathrm{C}\right) \\ 1 & 36.30 & 2220 & \\ 2 & 36.12 & 2202 & 2210 \pm 10 \\ 3 & 36.13 & 2203 & \\ 4 & 36.10 & 2200 & \end{array}$

In addition, a test piece sublimated completely in vacuum $\left(10^{-5} \mathrm{mmHg}\right)$ at temperatures above ca. $1900^{\circ} \mathrm{C} . \mathrm{CeO}_{2}$ sample also showed the similar vaporization in vacuum. Since $P_{\mathrm{O}_{2}}{ }^{1 / 2}$ is about $10^{-8} \mathrm{mmHg}$ in this vacuum, both $\mathrm{CeO}_{2}$ and $\mathrm{Ce}_{2} \mathrm{O}_{3}$ sample would change into the intermediate phase, $\mathrm{CeO}_{2-x}$. Friedrich obtained $1690^{\circ} \mathrm{C}$ for the melting point of $\mathrm{Ce}_{2} \mathrm{O}_{3}$ in nitrogen ${ }^{1)}$. But this value seems to be too low because the oxidation of $\mathrm{Ce}_{2} \mathrm{O}_{3}$ to $\mathrm{CeO}_{2-x}$ can not be prevented in nitrogen even if it was purified. The melting point values of rare earth oxides reported by various authors are summarized in Table 2 .

Table 2. Melting points of $\mathrm{Ln}_{2} \mathrm{O}_{3}$.

$\begin{array}{lccc}\mathrm{Ln}_{2} \mathrm{O}_{3} & \text { Temperature }\left({ }^{\circ} \mathrm{C}\right) & \text { Environment } & \text { References } \\ \mathrm{La}_{2} \mathrm{O}_{3} & 2210 \pm 20 & \mathrm{H}_{2} & 10 \\ & 2307 & \mathrm{Air} & 11 \\ & 2304 \pm 2 & \mathrm{~A} & 8 \\ \mathrm{Ce}_{2} \mathrm{O}_{3} & 2210 \pm 10 & \mathrm{H}_{2} & \text { This work } \\ & 1690 & \mathrm{~N}_{2} & 1 \\ \mathrm{Pr}_{2} \mathrm{O}_{3} & 2200 & - & 12 \\ \mathrm{Nd}_{2} \mathrm{O}_{3} & 2272 \pm 20 & \mathrm{He} & 10 \\ \mathrm{Sm}_{2} \mathrm{O}_{3} & 2300 \pm 50 & \mathrm{He}, \mathrm{H}, \text { Vac. } & 13 \\ & 2350 \pm 50 & \text { Air } & 14\end{array}$

The value, $2210 \pm 10^{\circ} \mathrm{C}$, obtained in this study is reasonable in comparison with the values of other oxides. It is interesting for engineering materials that rare earth sesquioxides have generally high melting points of above $2200^{\circ} \mathrm{C}$ and are stable up to the melting point.

\subsection{Thermal expansion coefficient}

A thermal expansion curve was represented by the following linear equation :

$$
\left(l_{2}-l_{1}\right) / l_{1}=\bar{\alpha}\left(t_{2}-t_{1}\right)
$$

where $l_{1}$ and $l_{2}$ are lengths of the specimen at 


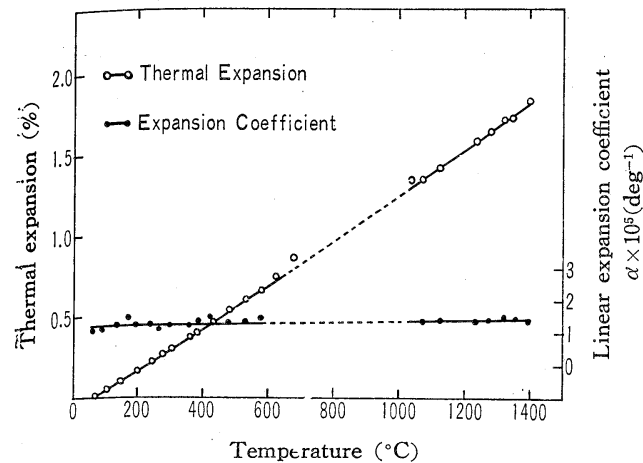

(a)

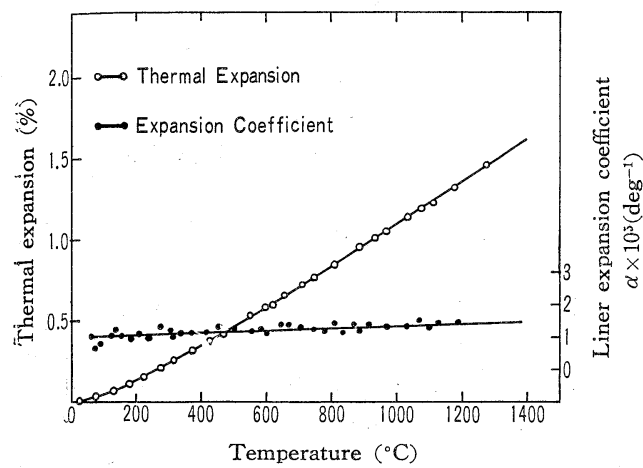

(b)

(a) $\mathrm{Ce}_{2} \mathrm{O}_{3}$ specimen in hydrogen.

(b) $\mathrm{CeO}_{2}$ specimen in air.

Fig. 5. Thermal expansion curves and linear expansion coefficients $(\alpha)$.

temperatures of $t_{1}$ and $t_{2}$, respectively. $\bar{\alpha}$ is the average value of the linear expansion coefficients between $t_{1}$ and $t_{2}$. The expansion curves and the calculated linear expansion coefficients for $\mathrm{Ce}_{2} \mathrm{O}_{3}$ and $\mathrm{CeO}_{2}$ are shown in Figure 5 (a) and 5 (b), respectively. Both $\mathrm{Ce}_{2} \mathrm{O}_{3}$ and $\mathrm{CeO}_{2}$ showed continuous expansion in all over the temperatures.

The calculated expansion coefficients are given as follows :

$$
\begin{aligned}
& \text { for } \mathrm{Ce}_{2} \mathrm{O}_{3} \quad \alpha=12.0 \times 10^{-6} \mathrm{deg}^{-1} \text { at a room } \\
& \text { temperature } \\
& \alpha=14.8 \times 10^{-6} \mathrm{deg}^{-1} \text { at } 1350^{\circ} \mathrm{C} \\
& \text { for } \mathrm{CeO}_{2} \quad \alpha=10.0 \times 10^{-6} \mathrm{deg}^{-1} \text { at a room } \\
& \text { temperature } \\
& \alpha=13.5 \times 10^{-6} \mathrm{deg}^{-1} \text { at } 1100^{\circ} \mathrm{C}
\end{aligned}
$$

Since an anomalous expansion owing to the formation of $\mathrm{CeO}_{2-x}$ from $\mathrm{Ce}_{2} \mathrm{O}_{3}$ was observed between $600^{\circ} \mathrm{C}$ and $1050^{\circ} \mathrm{C}$, no data was expressed in Figure 5 (a) in this temperature range.

The values of the expansion coefficients for $\mathrm{Ce}_{2} \mathrm{O}_{3}$ has not been published previously, but the values for $\mathrm{La}_{2} \mathrm{O}_{3}$ and $\mathrm{Nd}_{2} \mathrm{O}_{3}$ which have a similar structure to $\mathrm{Ce}_{2} \mathrm{O}_{3}$ have been reported. Those values and the results of this work are tabulated in Table

\begin{tabular}{|c|c|c|c|c|}
\hline Oxides & $\beta\left(\operatorname{deg}^{-1}\right)$ & Temp. range & $\left({ }^{\circ} \mathrm{C}\right) \quad$ Method & Reference \\
\hline \multirow{2}{*}{$\mathrm{La}_{2} \mathrm{O}_{3}$} & 35.9 & R.T.-1000 & Dilatometer & (15) \\
\hline & $37.9^{*}$ & R.T. -1100 & Dilatometer & (16) \\
\hline $\mathrm{Ce}_{2} \mathrm{O}_{3}$ & 40.5 & R.T. -1400 & Dilatometer & This work \\
\hline $\mathrm{Pr}_{2} \mathrm{O}_{3}$ & - & - & - & - \\
\hline \multirow[t]{2}{*}{$\mathrm{Nd}_{2} \mathrm{O}_{3}$} & 34.2 & R.T. -1050 & Dilatometer & (15) \\
\hline & $36.9^{*}$ & R.T. -1150 & Dilatometer & (16) \\
\hline \multirow[t]{4}{*}{$\mathrm{CeO}_{2}$} & 36.3 & R.T. -1000 & Dilatometer & (17) \\
\hline & 35.6 & R.T. -625 & High-temp. X-ray & (18) \\
\hline & 37.5 & R.T. -1000 & Dilatometer & (3) \\
\hline & 36.0 & R.T. -1100 & Dilatometer & This wor \\
\hline \multicolumn{5}{|c|}{ * Single crystal sample } \\
\hline \multirow{2}{*}{\multicolumn{3}{|c|}{ for a sintered specimen }} & \multicolumn{2}{|c|}{$\beta=3 \alpha \cdots \cdots \cdots \cdots \cdots(5)$} \\
\hline & & for a single crystal & \multicolumn{2}{|c|}{$\beta=2 \alpha_{a}+\alpha_{c} \cdots \cdots(6)$} \\
\hline
\end{tabular}
3 , and are compared with each other. The values of the volume expansion coefficient $(\beta)$ were calculated from the values of $\alpha$ by following relations:
Table 3. Volume thermal expansion coefficients $(\beta)$ of rare earth oxides.

Here $\alpha_{a}$ and $\alpha_{c}$ are the linear expansion coefficients along the $a$-axis and $c$-axis, respectively.

The value for $\mathrm{CeO}_{2}$ was in good agreement with the published values. But the value for $\mathrm{Ce}_{2} \mathrm{O}_{3}$ was greater than the expected value in ca. $11 \%$. It is supposed that the sample body was oxidizing into $\mathrm{CeO}_{2-x}$ of which molar volume is greater than those of both $\mathrm{Ce}_{2} \mathrm{O}_{3}$ and $\mathrm{CeO}_{2}(\max .8 \%)$ at the surface during the experiments.

\subsection{Electrical conductivity}

The relation of the logarithm of the electrical conductivity $(\log \sigma)$ versus the reciprocal absolute temperature $(1 / T)$ was shown by a straight line with a break at about $950^{\circ} \mathrm{C}$ (Figure 6). In a low temperature range, the conductivity at any temperature was found to be a similar value in any atmosphere except for air.

The electrical conductivity was represented in a following relation :

$$
\sigma=\sigma_{0} \exp (-E / k T)
$$

where $E$ is the activation energy for the electrical conduction. The following values were obtained

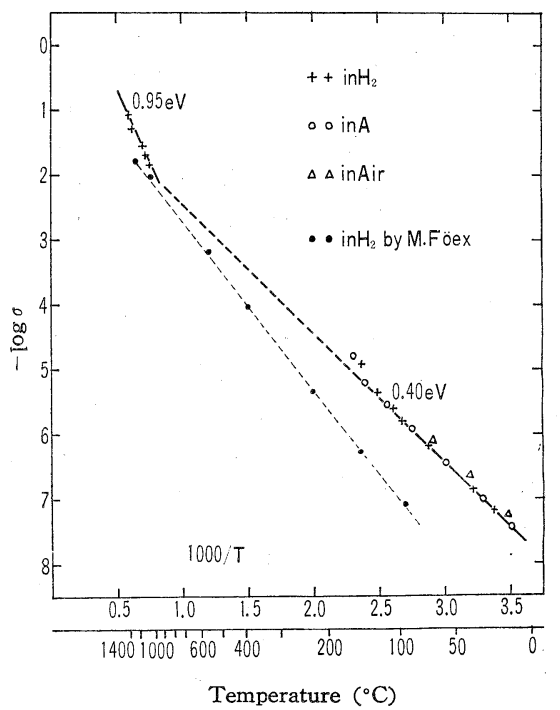

Fig. 6. The logarithm of electrical conductivity $(\log \sigma)$ vs. reciprocal absolute temperature $(1 / T)$. 
from the results in the low temperature range: $\sigma_{300^{\circ} \mathrm{K}}=7.7 \times 10^{-8} \Omega^{-1} \mathrm{~cm}^{-1}, \quad E=0.40 \mathrm{eV}$

For the high temperature range, $\sigma_{1673^{\circ} \mathrm{K}}=8.0 \times 10^{-2} \Omega^{-1} \mathrm{~cm}^{-1}, \quad E=0.95 \mathrm{eV}$

Since an anomalous conduction derived from the formation of $\mathrm{CeO}_{2-x}$ from $\mathrm{Ce}_{2} \mathrm{O}_{3}$ appeared in the temperature range of $150^{\circ} \sim 1050^{\circ} \mathrm{C}$, no result was represented in Figure 6 as the conduction of $\mathrm{Ce}_{2} \mathrm{O}_{3}$. It is supposed from these results that the conduction mechanisms are different between the low temperature range and the high temperature range.

The electrical conductivities of a series of the rare earth oxides were studied by W. Noddack and H. Walsh ${ }^{19)}$ and N.P. Bogoroditskii ${ }^{20)}$ in air, i.e. $\mathrm{CeO}_{2}$ was employed as a cerium oxide. Only M. Föex ${ }^{2)}$ studied the conductivity of $\mathrm{Ce}_{2} \mathrm{O}_{3}$ in cooling process in hydrogen. He, however, did not observe the break at about $950^{\circ} \mathrm{C}$. In most rare earth oxides, the break in the relation of $\log \sigma$ vs. $1 / T$ was observed between $700^{\circ} \mathrm{C}$ and $1000^{\circ} \mathrm{C}$, but its reasons have not been explained yet $^{21)}$.

Noddack and Bogoroditskii concluded that the conductions in the rare earth oxides were purely electronic, i.e. up to $99.7 \%$ by the latter. These workers, however, did not consider the variations in the sample composition of nonstoichiometric oxides $\left(\mathrm{Pr}_{6} \mathrm{O}_{11}, \mathrm{~Tb}_{4} \mathrm{O}_{7}\right.$, etc. $)$ of which compositions could be varied by $P_{\mathrm{O}_{2}}$ and temperatures. On the other hand, in studies on the conduction of $\mathrm{CeO}_{2}-$ $\mathrm{La}_{2} \mathrm{O}_{3}$ solid solutions which remained in a fluoritetype structure having much oxygen vacancies, $\mathrm{T}$. Takahashi and coworker ${ }^{22}$ indicated that the conduction was predominated by oxygen ions moving through the vacancies and found the activation energy for this mechanism to be about $1 \mathrm{eV}$. As described above, the conduction of the rare earth oxides was affected with the stoichiometry and $P_{\mathrm{O}_{2}}$. A study on the conductivity of near-stoichiometric $\mathrm{CeO}_{2}$ as a function of $P_{\mathrm{O}_{2}}$ was undertaken by E.H. Greener et al. ${ }^{23)}$. They found that $\mathrm{CeO}_{2}$ was $n$-type semiconductor, and assumed that the conduction in $\mathrm{CeO}_{2}$ was dominated by the electrons trapped at oxygen vacancies.

In addition, several studies of praseodimium oxides, $\mathrm{PrO}_{y}(1.5 \leqq y \leqq 2.0)$, which exists in two valence states $\left(\mathrm{Pr}^{3+}, \mathrm{Pr}^{4+}\right)$, were published recently. J.C. Conwell et al. ${ }^{24)}$, who studied the conduction and Seebeck coefficients of $\mathrm{PrO}_{y}$, found that $\mathrm{PrO}_{y}$ was $n$-type for $2.000 \geqq y \geqq 1.725$, $p$-type for 1.725 $>y \geqq 1.500$, and indicated that the conduction was understood by a sort of the hopping-type mechanism with electron transfer. On the other hand, L. Eyring et al. ${ }^{25}$ ) considered the contributions of ionic conduction in the range of $y$ value slightly greater than 1.50 at temperatures below $600^{\circ} \mathrm{C}$.
As described above, the conduction mechanisms of the rare earth oxides have not been completely understood and the conclusions appeared to be partly inconsistent with each other. In general, however, it is well known that the mixed valent oxides, $\mathrm{PrO}_{y}, \mathrm{CeO}_{2-x}, \mathrm{~Tb}_{4} \mathrm{O}_{7}$, etc., have greater conductivity and smaller activation energy (0.3 $0.6 \mathrm{eV})$ than those of tha stoichiometric oxides.

On the basis of above discussion, the results of this study may be considered qualitatively as follows; the conduction of $\mathrm{Ce}_{2} \mathrm{O}_{3}$ in the low temperature range appears to be electronic one of hopping-type by $\mathrm{Ce}^{4+}$ ions formed in the sample $\left(\mathrm{Ce}_{2} \mathrm{O}_{3.042}\right)$. The activation energy for this mechanism was found to be $0.40 \mathrm{eV}$. In the high temperature range, the intrinsic conduction of $\mathrm{Ce}_{2} \mathrm{O}_{3}$ appeared with the activation energy, 0.95 $\mathrm{eV}$, which was comparable with the values of other stable rare earth oxides.

In addition, the ionic contributions should be considered for oxides which have much oxygen vacancies, i.e. $\mathrm{PrO}_{y},(\mathrm{Ce}, \mathrm{La}) \mathrm{O}_{2-x}$, etc. It is reported that oxygen ions can move reasonably fast in those oxides ${ }^{26)}$. The mobility of ions, however, is thought to be smaller than that of electrons, so it is most probable that electrons are dominant for the conduction in the se oxides.

If the conduction in $\mathrm{Ce}_{2} \mathrm{O}_{3}$ was represented by the hopping-type mechanism $\left(\mathrm{Ce}^{3+} \rightleftharpoons \mathrm{Ce}^{4+}\right)$, the following relation was crudely expected :

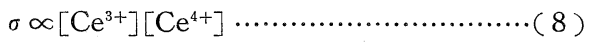

Indeed, it was observed that $\mathrm{CeO}_{2-x}$ showed an extremely higher conductivity than both $\mathrm{CeO}_{2}$ and $\mathrm{Ce}_{2} \mathrm{O}_{3}$.

\subsection{Magnetic susceptibility}

The relations of the molar magnetization $(M)$ versus the field strength $(H)$ are shown in Figure 7. They were represented by a straight line passing through the origin at each temperature, namely the following equation was satisfied.

$$
M=\chi_{m} \times H
$$

where $\chi_{m}$ is the molar magnetic susceptibility. As shown in Figure 8 , the relation of $1 / \chi_{m}$ versus $T$

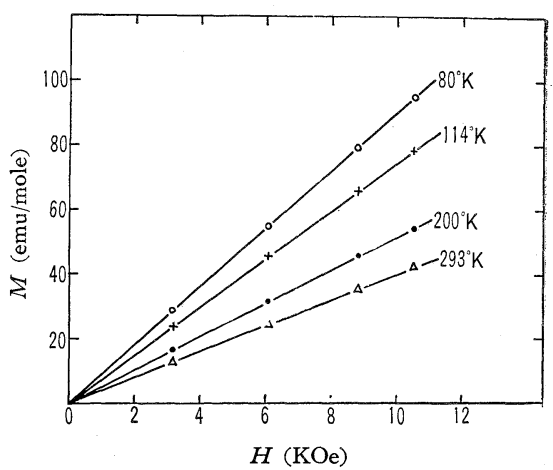

Fig. 7. Magnetization $(M)$ vs. field strength $(H)$ 


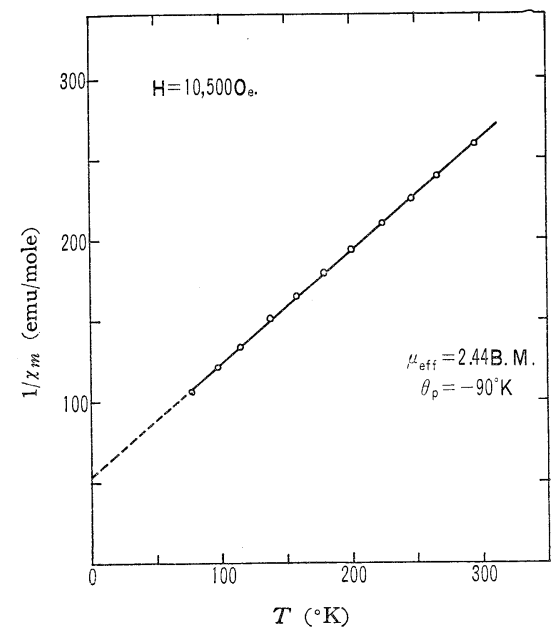

Fig. 8. Reciprocal molar susceptibility $\left(1 / \chi_{m}\right)$ vs. temperature $(T)$.

was linear in all over the temperature range studied following the Curie-Weiss law,

$$
\chi_{m}=C /\left(T-\theta_{p}\right)
$$

where $C$ is the Curie-Weiss constant, $\theta_{p}$ is the paramagnetic Curie temperature. From Figure 7 and 8 , it is well understood that $\mathrm{Ce}_{2} \mathrm{O}_{3}$ behaves paramagnetically in all over the temperatures studied, and following values were obtained: $\chi_{m 293^{\circ} \mathrm{K}}=3.90 \times 10^{-3} \mathrm{emu} / \mathrm{mole}$,

$$
\theta_{p}=-90^{\circ} \mathrm{K}, \quad C=0.728
$$

The effective magnetic moment $\left(\mu_{\text {eff }}\right)$ was calculated from the following relation,

$$
\mu_{\mathrm{eff}}=\sqrt{3 k C / N \mu_{B}}=2.83 \sqrt{\mathrm{C}} \text {...... }
$$

and was found to be $\mu_{\mathrm{eff}}=2.44$ Bohr Magnetons.

The electron structure of $\mathrm{Ce}^{3+}$ ion is shown in $1 s^{2} 2 s^{2} 2 p^{6} 3 s^{2} 3 p^{6} 3 d^{10} 4 f^{1} 5 s^{2} 5 p^{6}$. $\mathrm{Ce}^{3+}$ ion is characterized in having one unpaired electron $4 f^{1}$, and $5 s^{2} 5 p^{6}$ electrons in outer shell shield the effects of the crystalline field for $4 f^{1}$ electron. In other words, $\mathrm{Ce}^{3+}$ ion is regarded as a free ion at temperatures except for low temperatures. The results of this investigation are consistent with the above arguments. The theoretical effective magnetic moment for $\mathrm{Ce}^{3+}$ ion was calculated to be 2.56 B.M. by Van Vleck and A. Frank ${ }^{26)}$. The experimentally determined value, 2.44 B.M., was in good agreement with the literature values ${ }^{27}$ obtained for $\mathrm{Ce}^{3+}$ aqueous solutions. No prior studies on the magnetic susceptibility for $\mathrm{Ce}_{2} \mathrm{O}_{3}$ are found, but the susceptibility for $\mathrm{Pr}^{4+}$ oxides, isoelectronic with $\mathrm{Ce}^{3+}$, were measured as follows :

for $\mathrm{PrO}_{2.007}{ }^{28)} \quad \mu_{\mathrm{eff}}=2.51 \mathrm{~B} . \mathrm{M} . \quad \theta_{p}=-90.1^{\circ} \mathrm{K}$

for $\mathrm{PrO}_{2.00}{ }^{29)} \quad \mu_{\mathrm{eff}}=2.47$ B.M. $\theta_{p}=-105^{\circ} \mathrm{K}$

These values are in good agreement with the results of this investigation. The negative $\theta_{p}$ values indicates that the interaction of $4 f^{1}-4 f^{1}$ is antiferromagnetic and an antiparallel ordering should occur below $77^{\circ} \mathrm{K}$.

\section{Conclusion and summary}

There are few previous studies on the properties of $\mathrm{Ce}_{2} \mathrm{O}_{3}$, which was obtained from $\mathrm{CeO}_{2}$ by the reduction with hydrogen at $1400^{\circ} \mathrm{C}$. Powdered or sintered samples were used for experiments. The results obtained were as follows.

(1) It was recognized that $\mathrm{Ce}_{2} \mathrm{O}_{3}$ was very unstable and was slowly oxidizing to $\mathrm{CeO}_{2}$ in air even at a room temperature. The oxidation process was so exothermic that a spontaneous ignition was often observed. It was also observed that $\mathrm{Ce}_{2} \mathrm{O}_{3}$ changed into $\mathrm{CeO}_{2-x}$ in ordinary atmospheres, i.e. vacuum, argon, nitrogen, hydrogen, etc, at temperatures between several hundreds and one thousand degrees in centigrade. The compositions of $\mathrm{CeO}_{2-x}$ were varied by $P_{\mathrm{O}_{2}}$ and temperatures. $\mathrm{Ce}_{2} \mathrm{O}_{3}$ hardly dissolved in acids and alkalis but reacted with water.

(2) The melting point of $\mathrm{Ce}_{2} \mathrm{O}_{3}$ was found to be $2210 \pm 10^{\circ} \mathrm{C}$, which is comparable with the values of other rare earth oxides. $\mathrm{Ce}_{2} \mathrm{O}_{3}$ was stable in hydrogen up to the melting point without decomposition. On the other hand, $\mathrm{CeO}_{2-x}$ seemed to be unstable.

(3) The thermal expansions $\mathrm{Ce}_{2} \mathrm{O}_{3}$ and $\mathrm{CeO}_{2}$ were studied between a room temperature and $1400^{\circ} \mathrm{C}$, and were found to be linear without a discontinuity induced by the crystal transformations. Experimentally determined linear expansion coefficients were as follows :

$$
\text { for } \begin{aligned}
\mathrm{Ce}_{2} \mathrm{O}_{3} \quad \alpha_{R T} & =12.0 \times 10^{-6} \mathrm{deg}^{-1} \\
\text { for } \mathrm{CeO}_{2} \quad \alpha_{1350^{\circ} \mathrm{C}} & =14.8 \times 10^{-6} \mathrm{deg}^{-1} \\
\alpha_{R T} & =10.0 \times 10^{-6} \mathrm{deg}^{-1} \\
\alpha_{1100^{\circ} \mathrm{C}} & =13.5 \times 10^{-6} \mathrm{deg}^{-1} .
\end{aligned}
$$

(4) The electrical conductivity of $\mathrm{Ce}_{2} \mathrm{O}_{3}$ was measured from a room temperature to $1400^{\circ} \mathrm{C}$. The relation of $\log \sigma$ vs. $1 / T$ was shown by a straight line with a break at about $950^{\circ} \mathrm{C}$. The following results were obtained :

$$
\begin{array}{rlrl}
\sigma_{300^{\circ} \mathrm{K}} & =7.7 \times 10^{-7} \Omega^{-1} \mathrm{~cm}^{-1} & E & =0.40 \mathrm{eV} \\
\sigma_{1673^{\circ} \mathrm{K}} & =8.0 \times 10^{-2} \Omega^{-1} \mathrm{~cm}^{-1} & E & =0.95 \mathrm{eV}
\end{array}
$$

It is assumed that the conduction mechanism in: the low temperature range was similar to that of mixed valent oxides, i.e. $\mathrm{PrO}_{y}, \mathrm{~Tb}_{4} \mathrm{O}_{7}, \mathrm{CeO}_{2-x}$, etc. Namely, a sort of the hopping-type conduction mechanism with formation of $\mathrm{Ce}^{4+}$ ion is supposed. The intrinsic conduction of $\mathrm{Ce}_{2} \mathrm{O}_{3}$, of which mechanism is similar to that of other stable rare earth oxides, was presented in the high temperature range.

(5) The magnetic susceptibility of $\mathrm{Ce}_{2} \mathrm{O}_{3}$ was. studied between $77^{\circ} \mathrm{K}$ and $300^{\circ} \mathrm{K}$. $M$ vs. $H$ were shown by straight lines passing through the origin. at each temperature. In addition, $1 / \chi$ vs. $T$ was. represented by a straight line, so the Curie-Weiss. law was confirmed to follow. The results obtained. are as follows : 


$$
\theta_{p}=-90^{\circ} \mathrm{K} \quad \mu_{\text {eff }}=2.44 \text { B.M. }
$$

These are comparable with the theoretical or experimental values in literatures.

A part of this work has been presented at the 19th Annual Meeting of The Chemical Society of Japan in Tokyo, in April 1966.

\section{References}

1) E. Friedrich and L. Sittg, Z. anorg. allgem. Chem. 145, 127 (1925).

2) M. Föex, Bull. Soc. Chim. 11, 6 (1944).

3) M. Föex, Compt. rend. 222, 660 (1946).

4) D.J. Bevan, J. Inorg. Nucl. Chem. 1, 49 (1959).

5) D.J. Bevan and J. Cordis, J. Inorg. Nucl. Chem. 26, 9 (1964).

6) C.H. La Blanshetais, J. recherches CNRS Lab. Bellevue (No. 29), 103 (1954).

7) T. Sata and M. Yoshimura, Bull. of Tokyo Institute of Technology, No. 84 (1968).

8) T. Sata, Bull. of Tokyo Institute of Technology, 53, 39 (1963).

9) F.A. Kuznetzov and T.N. Rezukhina, Zh. Fiz. Khim. 35, No. 5 (1961).

10) W.A. Lambertson and F.H. Gunzel, U.S. Atomic Energy Comm. AECD-3465, 1 (1952).

11) H. von Wartenburg and H.J. Reusch, Z. anorg. allgem. Chem. 208, 378 (1932).

12) F. Weigel, 5th Rare Earth Research Conf. Book III (1965).

13) L.G. Wisnyi and S. Pijanowskii, U.S. Atomic Energy Comm. TID-7530 (Pt. 1) 46 (1957).

14) C.E. Curtice and J.R. Johnston, J. Am. Ceram.
Soc. 40 [1] 15 (1957).

15) R.E. Mistler, G.L. Ploetz and J.A. Smith, J. Am. Ceram. Soc. 46 [11] 561 (1963).

16) S. Stecura and W.J. Campbell, U.S. Bur. Mines Rept. Invest. No. 5847 (1961).

17) L.R. Wilfong, L.P. Domingues, et al., U.S. Bur. Mines Rept. Invest. No. 6180 (1963).

18) P.C. Mahanta, J. Hatibarua and R.K. Das, J. Sci. Ind. Res. (India), 21 B, 596 (1962).

19) W. Noddack and H. Walsch, Z. Elektrochem. 63, 269 (1959).

20) N.P. Bogoroditskii, Soviet Phys. Dokl. 10 [1] 85 (1965).

21) J. Rudolph, Z. Natrfor. 14 a, 727 (1959).

22) T. Takahashi and H. Iwahara, Denki Kagaku, (J. of the Electrochemical Society, Japan) 34 [4] 254 (1966).

23) E.H. Greener, J.M. Wimmer and W.M. Hirthe, p. 539 "Rare Earth Research(II)" Edited by K.S. Vorres, Gordon \& Breach, (1964).

24) J.C. Conwell, A.A. Cella and J.M. Honig, p. 555 "Rare Earth Research (II)" Edited by K.S. Vorres, Gordon \& Breach (1964).

25) L. Eyring and N.C. Beanziger, J. Appl. Phys, 33, 428 (1962).

26) P.A. Faeth and A.F. Clifford, J. Phys. Chem. 67 [7] 1453 (1963).

27) J.H. van Vleck and A. Frank, "Theory of Electric and Magnetic Susceptibilities" Oxford Univ. Press, p. 226 (1932).

28) S. Kern, J. Chem. Phys. 40, 208 (1964).

29) J.B. MacChesney, J. Chem. Phys. 41, 3177(1964). [Received Sep. 11, 1967]

\title{
三ニ酸化セリウムの材料物 性
}

\author{
佐多敏之・吉村昌弘 \\ （東京工業大学工業材料研究所）
}

三二酸化セリウム $\left(\mathrm{Ce}_{2} \mathrm{O}_{3}\right)$ の材料物性は, 従来ほと んど検討されていなかった. $\mathrm{Ce}_{2} \mathrm{O}_{3}$ は二酸化セリウム $\left(\mathrm{CeO}_{2}\right)$ を水素中 $1400^{\circ} \mathrm{C}$ 以上で還元して得られる。 こ のようにして得た焼結体および粉末を用いて測定を行な い，以下の結果を得た。

(1) $\mathrm{Ce}_{2} \mathrm{O}_{3}$ は極めて酸化しやすく, 空気中では室温 でも酸化の進行が認められ，加熱した場合は約 $60^{\circ} \mathrm{C}$ 以 上で急激に酸化し $\mathrm{CeO}_{2}$ になった。 字た通常の真空中， アルゴン中，水素中でも数 $100^{\circ} \mathrm{C}$ から $1000^{\circ} \mathrm{C}$ の温度 では，いくらか酸化して中間相 $\left(\mathrm{CeO}_{2-x}\right)$ を生成した. アルカリには不溶, 酸にはゆっくり溶け, 水と反応して 水和物をつくることが観察された。

(2) $\mathrm{Ce}_{2} \mathrm{O}_{3}$ の小片を水素気流中, タングステン炉で 融点を測定し, $2210 \pm 10^{\circ} \mathrm{C}$ の值を得た. $\mathrm{Ce}_{2} \mathrm{O}_{3}$ は水素 中で融点まで安定に存在したが, 中間相は不安定であっ た.
(3) 熱膨脹の測定から, 線膨脹係数として, $\mathrm{Ce}_{2} \mathrm{O}$ に対しては室温で $12.0 \times 10^{-6} \mathrm{deg}^{-1}, 1350^{\circ} \mathrm{C}$ で $14.8 \times$ $10^{-6} \mathrm{deg}^{-1}$ が， $\mathrm{CeO}_{2}$ に対しては室温で $10.0 \times 10^{-6} \mathrm{deg}^{-1}$, $1100^{\circ} \mathrm{C}$ で $13.5 \times 10^{-6} \mathrm{deg}^{-1}$ が得られた。

(4) 電気伝導度の対数 $\log \sigma$ と温度 $T$ との関係は, 約 $950^{\circ} \mathrm{C}$ にクニックを持つ直線で表わされる． $\sigma_{300} \mathrm{~K}=$ $7.7 \times 10^{-7} \Omega^{-1} \mathrm{~cm}^{-1}, \sigma_{1673^{\circ} \mathrm{K}}=8.0 \times 10^{-2} \Omega^{-1} \mathrm{~cm}^{-1}$ で活性化 エネルギーは高温域で $0.95 \mathrm{eV}$, 低温域で $0.40 \mathrm{eV}$ で, 低温域では， $\mathrm{Ce}^{4+}$ の混入による一種のホッピング型電 導が現われたものとみなされる。

(5) $77^{\circ} \mathrm{K}$ から $300^{\circ} \mathrm{K}$ の間で, $\mathrm{Ce}_{2} \mathrm{O}_{3}$ の磁化 $(M)$ と磁場 $(H)$ の関係および， $1 / \chi$ と $T$ の関係はいずれ も直線的で常磁性的挙動を示した. $\theta_{p}=-90^{\circ} \mathrm{K}, \mu_{\mathrm{eff}}=$ 2.44 B.M. は理論值と良く一致した。

(9/11/1967 受付) 